УДК 006.91: 620.179.16

${ }^{1}$ Витвицька Л.А., ${ }^{2}$ Лаврук Х.З., ${ }^{1}$ Чуйко М.М. , ${ }^{2}$ Витвицький 3.Я.

${ }^{1}$ Івано-Франківський національний технічний університет нафти і газу

${ }^{2}$ Івано-Франкіський національний медичний університет

\title{
УДОСКОНАЛЕНИЙ МЕТОД ЕЛАСТОГРАФІЇ КРОВОНОСНИХ СУДИН
}

Анотація Проведено аналіз існуючих методів ультразвукового контролю людського організму. Обгрунтовано доцільність проведення еластографії сонних артерій 3 метою діагностики атеросклерозу і ступеня нерухомості атеросклеротичних бляшок у судинах. Теоретично обгрунтовано доцільність проведення еластографії з використанням зсувних хвиль, які виникають при застосуванні радіаційного тиску сильного сфокусованого ультразвукового імпульсу. Розроблено конструкцію електронного ультразвукового сканера, який забезпечує високу чутливість прийнятих сигналів на різних глибинах з високою роздільною здатністю. Визначено параметри ультразвукових датчиків, розроблена методика проведення дослідження, яка забезпечує проведення контролю на різних глибинах, показано приклад проведення еластографії сонних артерій.

Ключові слова: ультразвукові коливання, еластографія, атеросклеротичні бляшки, зсувна хвиля

Вступ та постановка проблеми. На даний час широке застосування знаходять ультразвукові методи діагностики людського організму. Це пояснюється як нешкідливістю проникаючих ультразвукових коливань (надалі УЗК) в порівнянні з рентгенівськими, так і з їх високою інформативністю щодо стану окремих структур організму. Поряд із використанням класичних ультразвукових методів, основаних на визначенні амплітуди, швидкості, зміни по фазі УЗК, відбитих і заломлених від структур з різним акустичним опором, на даний час все ширше використовуються методи візуалізації пружних характеристик м'яких тканин людського організму, які, в загальному, носять назву методів еластографії. Ці методи базуються на створенні деформацій досліджуваних тканин організму i визначенні характеристик відбитої хвилі в залежності від пружності цих тканин. Пружна реакція середовища на об'ємну і зсувну деформацію призводить до появи зворотніх сил, які прагнуть повернути тіло в початковий стан. За інерцією тіло проходить положення рівноваги i деформується в іншу сторону. Подібним чином виникають і коливання об'єму, і коливання форми, які поширюються в середовищі у вигляді хвиль.

Зараз еластографія вважається третьою ультразвуковою технологією. Завдяки їй відбувся значний якісний стрибок у диференціальній діагностиці вогнища патології поверхнево розташованих тканин. Інформативність еластографії обумовлена тим, що більшість злоякісних утворень, як правило, мають більш щільну структуру, ніж навколишні тканини і доброякісні пухлини. У той же час на звичайному ультразвуковому зображенні їх іноді практично неможливо розрізнити [1].

Мета роботи. На даний час еластографія найбільше використовується для діагностики щитовидної залози та печінки. Однак виникає необхідність контролю стану кровоносних судин, діагностика яких еластографічними методами затруднена в силу постійного руху крові, пульсацій кров'яного тиску і складності отримати пружну зсувну хвилю, яка б не залежала від швидкості кровотоку. Особливо необхідним на даний час $є$ діагностика атеросклерозу. Що таке атеросклероз? Це поширене і небезпечне захворювання, що спричиняє інфаркти та інсульти. Небезпека полягає у тому, що хвороба розвивається безсимптомно. Механізм розвитку атеросклерозу полягає в накопиченні холестерину, який у вигляді бляшок відкладається у великих і середніх судинах. Це призводить до зниження кровотоку, підвищення артеріального тиску. Симптоматика конкретного випадку залежить від локалізації бляшки і іiі розмірів, точніше, ступеня закриття нею просвіту судини. При цьому необхідним $\epsilon$ встановлення структури бляшок, від якої залежить можливість іiї відриву, що призводить до утворення тромбів і тромбоемболії. Саме еластографія дозволяє визначити ступінь затвердіння бляшок і ії нерухомість у судині. Найбільш доцільно досліджувати стан сонних артерій, які $\epsilon$ поверхневими і в яких часто утворюються атеросклеротичні бляшки [2]. Завдання визначення пружних характеристик стінок судин, включаючи атеросклеротичних включень в них,

( ) Витвицька Л.А., Лаврук Х.З., Чуйко М.М., Витвицький 3.Я. 
пов'язана з діагностикою “периферійної артеріальної хвороби” і з визначенням небезпеки відриву тромбу. Вважається, що найбільшу небезпеку представляють м’які включення 3 ліпідним ядром і тонкою фіброзною капсулою.

Більшість сучасних клінічних підходів до оцінки стану судин нижніх кінцівок зводяться більше до оцінки ступеня стенозу і зменшення просвіту судин, ніж до оцінки характеристик атеросклеротичних утворень. Тому дана робота присвячена розробленню удосконаленого методу еластографії саме сонних артерій.

Результати роботи. Для розроблення удосконаленого методу діагностики сонних артерій було розглянуто різні існуючі способи створення деформацій. Будь-яка деформація твердого тіла може бути віднесена до одного 3 двох видів: деформації розтягування-стиснення (компресійна), і деформації зсуву (зсувна). Відповідь твердого тіла на прикладене зусилля описується модулями пружності, які характеризують його здатність пружно деформуватися при прикладанні до нього сили. Оскільки кровоносні судини за структурою стінок відносяться до м’язевих тканин, то для їх діагностики доцільно використовувати еластографію.

Для діагностики сонних артерій пропонується проводити еластографію на зсувних хвилях, яка, на відміну від компресійної, не вимагає компресії тканин датчиком. Тим самим досягається візуалізація більш високої точності і більш високої якості. Хвиля коливань форми при незмінному об'ємі, або зсувна хвиля, - це поперечна хвиля, при якій коливання частинок відбуваються в площині, перпендикулярній до напрямку поширення хвилі. Зсувна хвиля рухається із швидкістю, яка залежить від відношення модуля зсувної пружності $\mu$ до щільності середовища $\rho$ :

$$
C_{U S}=\sqrt{\frac{\mu}{\rho}}
$$

Суть методу полягає у випромінюванні ультразвукового імпульсу в обрану точку і у відстеженні викликаних ним згасаючих коливальних рухів тканин шляхом випромінювання в наступні моменти часу декількох зондуючих імпульсів, від кожного з яких реєструвати одномірні ехограми. Подальшою обробкою ехограм визначається зміщення у досліджуваній області за відповідними пружними характеристиками тканин. Для усунення артефактів від пульсації судин необхідно забезпечити синхронізацію часу знімання інформації $з$ діастоли за сигналами електрокардіограми. Для зменшення часу сканування досліджуваної області (площею до 30 мм) необхідно здійснювати паралельний прийом відразу чотирьох зондуючих променів після одного генеруючого імпульсу.

Для збудження коливань в тканинах доцільно використовувати несучу частоту імпульсу 7,2 МГц. Тривалість імпульсу становить до 70 мкс на глибинах до 3,5 см і 140 мкс на більших глибинах. У зондуючих імпульсах для збільшення просторової роздільної здатності використовується несуча частота 7,2 МГц. Приклад отриманої ехограми і еластограм хворої судини наведений на рис.1. На ехограмі як світла область видно ділянки кальцинованого атеросклеротичного ураження стінки артерії. На еластограмі їй відповідає область малих деформацій

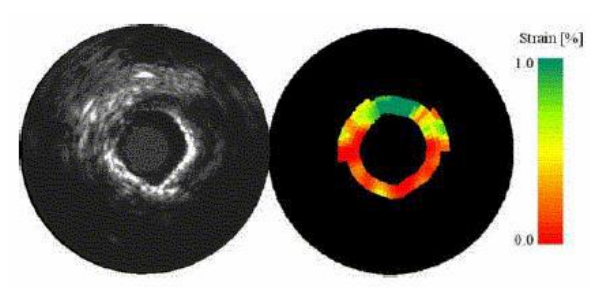

Рис. 1. Ехограма і відповідна еластограма сонної артерії, отримані в період обстеження

Як показали вимірювання, зсувний модуль пружності м'яких тканин малий у порівнянні 3 модулем всебічного стиснення, і зсувна хвиля є “повільною”. Дійсно, швидкість ультразвуку в тканинах приблизно така ж, як у воді, тобто $C_{U S}=1500 \mathrm{~m} / \mathrm{c}$. Тому саме за допомогою зсувної хвилі можна досліджувати структуру внутрішніх стінок артерій з врахуванням пульсацій крові у них Джерелами зсуву можуть бути низькочастотні пульсації, створювані серцем і судинами, достатньо високочастотні зсувні хвилі, які випромінюються взаємодіючими ультразвуковими

○ Витвицька Л.А., Лаврук Х.З., Чуйко М.М., Витвицький 3.Я. 
пучками або одним сфокусованим ультразвуковим пучком за рахунок радіаційного тиску [3]. Пропонується технологія створення зсувних хвиль, що використовує радіаційний тиск сильного сфокусованого ультразвукового імпульсу. Цей спосіб отримання зсувних хвиль дозволяє отримати кількісну інформацію про пружність тканин, але тільки на заданій глибині в зоні фокусу. Для отримання зсувних хвиль на інший глибині треба змістити зону фокуса ближче або далі від датчика і вже в ній створити новим потужним ультразвуковим імпульсом необхідний тиск для отримання зсувних хвиль і виміряти їх характеристики. Вибір місця для вимірювання швидкості зсувної хвилі проводиться за допомогою пробного об'єму на двомірному ультразвуковому зображенні, а числові значення показника пружності видаються в метрах за секунду або перераховуються в кілопаскалі. При цьому створюються сфокусовані точки максимального тиску, в результаті чого зсувні хвилі формують фронт у вигляді так званого конуса Маха (рис. 2). Рух цього фронту відстежується за допомогою спеціального ультразвукового сканування, при цьому ділянки з різною швидкістю зсувних хвиль кодуються різними відтінками сірого кольору або різними кольорами за шкалою з певною кількістю колірних комірок, що дає можливість візуально виявляти зони 3 різною еластичністю. Так, шляхом отримання зсувних хвиль i обчислення їх швидкостей у всьому діапазоні досліджуваних глибин 3 подальшим колірним картуванням створюється двомірне кольорове зображення пружності тканин, що i $є$ колірною еластограмою зсувної хвилі. Зазвичай, червоним кольором маркуються більш пружні, тверді структури, використовуючи його як сигнал наявності атеросклеротичних змін на тлі синьо-блакитного фону нормальних тканин. Колірну еластограму можна переглядати в режимі реального часу окремо, а можна накласти на сірошкальне зображення або зіставити поруч з ним в двох паралельних вікнах. Після вивчення колірних еластограм проводиться еластометрія за допомогою одного або кількох пробних об'ємів з міліметровою роздільною здатністю. Можна заміряти пружність тканини однієї конкретної ділянки і порівняти ії з показником іншої ділянки. Цифрові дані можуть бути представлені у вигляді показників швидкості зсувних хвиль (в м/с) або пружності тканини (кПа). Можливість отримання абсолютних цифрових значень пружності різних органів і тканин в нормі і при патології є великою перевагою еластографії зсувної хвилі, і значно підвищує відтворюваність методу.

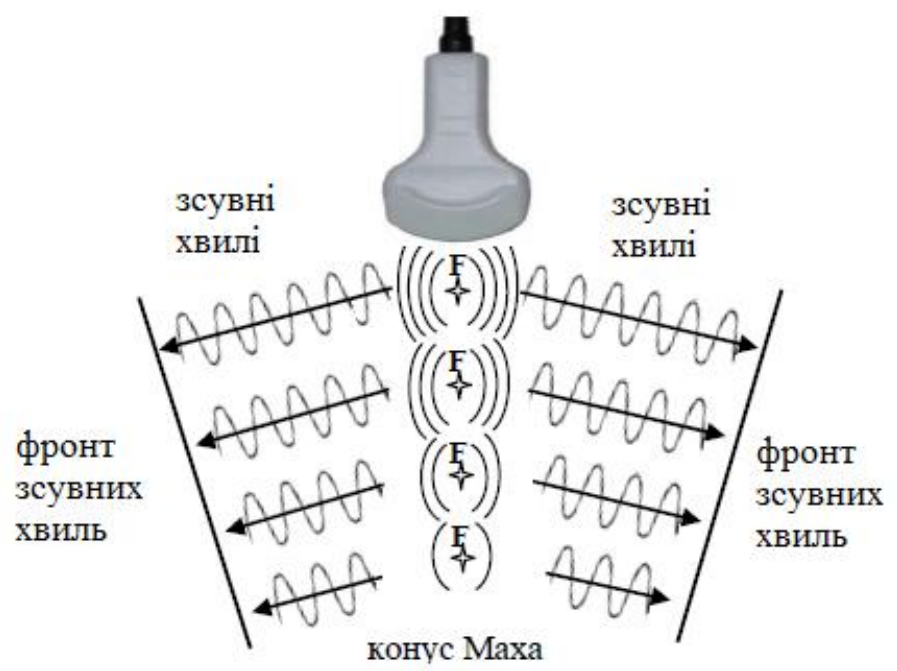

Рис. 2. Формування фронту зсувних хвиль (конус Маха) за допомогою сфокусованих точок (F1-F4) максимального тиску, послідовно створюваних на різній глибині з певною часовою затримкою

Структурна схема електронного блоку ультразвукового сканера показана на рис. 3. На ньому можна побачити основні елементи електронного блоку: формувач хвилі, формувач променя. Ехо-сигнали, прийняті датчиком і перетворені ним в електричні сигнали, потрапляють в електронний блок на вхід формувача променя. Основне його призначення, яке слідує із назви, - забезпечити необхідну форму УЗ променя на передачу і прийом. Формувач хвилі - це багатоканальний пристрій, з'єднаний з датчиком кабелем 3 великою кількістю провідників, кількість яких співпадає із загальним числом елементів п’єзоперетворювача. Кількість

() Витвицька Л.А., Лаврук Х.З., Чуйко М.М., Витвицький 3.Я. 
елементів в п'єзоперетворювачі в залежності від складності приладу може змінюватися для датчиків електронного сканування в діапазоні від 80 до 512 і вище, така ж буде кількість з’єднувальних проводів.

У каналах формувача променя здійснюється фокусування на приймання шляхом виставлення визначених значень затримок сигналів в кожному з каналів.

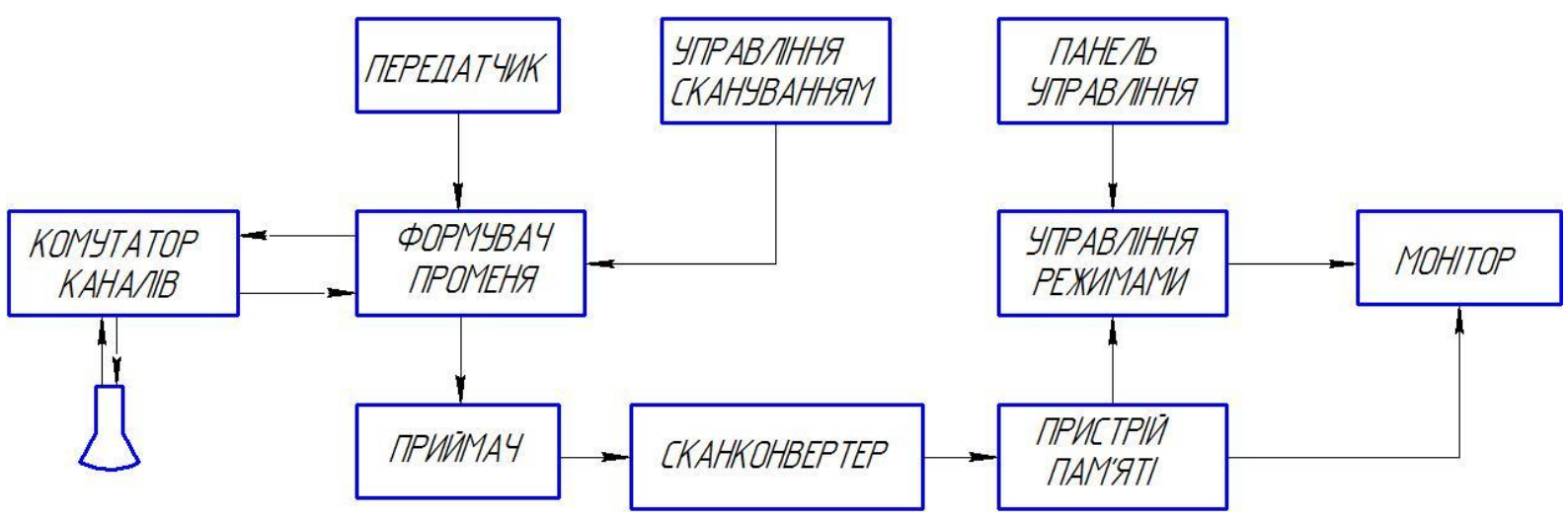

Рис. 3. Структурна схема електронного блоку ультразвукового діагностичного сканера

На вході формувача променя стоїть комутатор, в якому з великого числа проводів вибирається, як правило, менша кількість, яка дорівнює кількості каналів приймача i передавача. Комутатор на вході формувача виконує роль пристрою, що забезпечує сканування (переміщення) УЗ променя в датчиках лінійного і конвексного типу. Сканування здійснюється за сигналами пристрою керування скануванням.

Якщо прилад допускає одночасне приєднання декількох датчиків, то за допомогою додаткового перемикача кожен 3 датчиків може підключатися до комутатора і формувача УЗ променя. Вибір того чи іншого датчика здійснюється за сигналами, що надходять від клавіатури після натискання потрібної клавіші.

Передатчик генерує сигнали для випромінювання всередину досліджуваного тіла, $\epsilon$ багатоканальним пристроєм, який по кожному із каналів повинен передавати на формувач променя короткі електричні імпульси. Основні завдання, виконувані передатчиком:

- генерувати імпульси якомога меншої довжини (чим коротший імпульс, тим краща повздовжня роздільна здатність приладу);

- забезпечувати амплітуду імпульсів необхідного рівня ( чим більша амплітуда, тим більша чутливість), але не більше допустимого з точки зору безпеки пацієнта;

- здійснювати зсув після затримки між імпульсами для формування УЗ променя на передачу з потрібним фокусом;

- змінювати робочу частоту імпульсів $(5 ; 9 ; 10 ; 18$ МГц) в залежності від вибраного типу датчика.

Приймач отримує від формувача променя ехо-сигнали по багатьох каналах одночасно, він повинен підсилювати ці сигнали, піддавати їх відповідним перетворенням, сумувати сигнали всіх каналів і подавати сумарний сигнал на сканконвертер. Ехо-сигнали підсилюються в приймачі в 1-100 тис. раз по амплітуді (60-100 дБ). Підсилення може змінюватися за бажанням дослідника за допомогою кнопки підсилення на клавіатурі приладу.

Крім загального підсилення сигналів, можна регулювати підсилення по зонах глибини. Основне призначення цього регулювання - компенсувати затухання в різних зонах глибини в залежності від властивостей досліджуваної області. Рівень приймаючих ехо-сигналів внаслідок затухання помітно зменшується 3 глибиною, наприклад, рівень сигналу, отриманого внаслідок відбиття від неоднорідності на глибині $10 \mathrm{~cm}$, може бути в 1 тис. раз меншим по амплітуді, ніж рівень сигналу від того ж відбиття на глибині 1 см. У зв'язку з цим в приймачі здійснюється регулювання підсилення в залежності від глибини: чим більша глибина, тим більше підсилення. Правильне регулювання забезпечує компенсацію затухання сигналу в залежності від глибини таким чином, щоб максимальні рівні амплітуд ехо-сигналів були наближено однаковими у всьому діапазоні глибин. В цьому випадку забезпечується рівномірність яскравості зображення і висока діагностична інформативність на всіх глибинах.

○ Витвицька Л.А., Лаврук Х.З., Чуйко М.М., Витвицький 3.Я. 
Ще одна функція приймача - стиснення і регулювання динамічного діапазону ехосигналів, визначаючого відношення максимального і мінімального сигналів.

Зміна діапазону робочих частот - це також функція приймача. Кожний прилад повинен працювати 3 набором датчиків, які мають різні частоти. Через це діапазон частот прийому необхідно змінювати при перемиканні приладу на роботу з датчиком, який має іншу частоту, щоб забезпечити найкращу якість прийому ехо-сигналів.

Сканконвертер - це цифровий пристрій, який служить для перетворення інформації, отриманої в процесі сканування 3 виходу приймача, у форму, найбільш зручну для відображення на екрані приладу. В процесі сканування прийом сигналів проходить в області УЗ променя. При цьому вимірюються полярні координати кожного сигналу - глибина, кут, а також амплітуда сигналу.

3 виходу сканконвертора інформація, підготовлена для відображення, поступає у цифровий пристрій пам'яті, де записується 3 тією швидкістю, з якою проходить сканування. 3 кожним новим циклом сканування проходить запис нового кадра за рахунок витіснення інформації отриманої з попереднього кадра.

Пристрій пам'яті дозволяє реалізувати дуже важливий метод підвищення якості зображення, який називається “усереднення по кадрах". Основний недолік методу усереднення по кадрах - зниження реальної частоти кадрів, більш помітне, чим вищий рівень усереднення.

Оперативне управління роботою всіх елементів i вузлів електронного блоку здійснюється за допомогою основного процесора відповідно до програми, розробленої індивідуально для даного приладу. Крім основного процесора, в залежно від складності приладу можуть використовуватися додаткові процесори, наприклад для управління скануванням, виконання функцій сканконвертера, обробки результатів вимірювань і т.д.

Висновки:

1. Обгрунтовано доцільність проведення еластографії сонних артерій з метою діагностики атеросклерозу і стану атеросклеротичних бляшок.

2. Проведення еластографії з використанням зсувних хвиль, які виникають при застосуванні радіаційного тиску сильного сфокусованого ультразвукового імпульсу, дозволяє визначати щільність атеросклеротичних бляшок, ступінь їх нерухомості i небезпеку виникнення тромбоемболії у людському організмі .

3. Розроблена конструкція електронного ультразвукового сканера забезпечує високу роздільну здатність прийнятих ехо-сигналів, відбитих на різних глибинах і в мінімальному діапазоні часових інтервалів.

4. Розроблена методика проведення дослідження показала високу інформативність еластографії сонних артерій.

\title{
Література
}

1. Ультразвукова еластографія: теорія і практика створення навчального тренажера/ О.Б. Динник, М.М. Жайворонок, Н.М. Кобиляк, М.С. Харченко// Променева діагностика, променева терапія.-№ 3.-2014.-С.42-53

2. Кузик Ю.І. Атеросклероз сонних артерій: особливості патоморфологічної картини/ Ю.І.Кузик // Медицина транспорту України.- № 4.- 2011.-С.12-16

3. Руденко О. В. Физические основы эластографии. Часть 2. Эластография на сдвиговой волне (лекция) / О. В. Руденко, Д. В. Сафонов, П. И. Рыхтик, С. Н. Гурбатов //Радиология-Практика. 2014. - № 4 (46). - С. 62-72.

\author{
${ }^{1}$ Vytvytska L.A., ${ }^{2}$ Lavruk H.Z., ${ }^{1}$ Chuiko M.M., ${ }^{2}$ Vytvytsky Z.Y. \\ ${ }^{1}$ Ivano-Frankivsk National Technical University of Oil and Gas \\ ${ }^{2}$ Ivano-Frankivsk National Medical University
}

\section{ADVANCED METHOD OF ELASTOGRAPHY BLOOD ARTERIES}

The existing methods of ultrasonic control of the human body are analyzed. The expediency of carotid elastography for the diagnosis of atherosclerosis and the degree of immobility of atherosclerotic plaques in vessels is substantiated. It is theoretically justified the feasibility of conducting elastography on the shear waves that arise when using the radiation pressure of a strong focused ultrasonic pulse. The design of an electronic ultrasonic scanner has been developed, which provides high sensitivity of the received signals at different depths with high resolution. Utrasonic 
sensors parameters are determined, the technique of carrying out of the research providing control at different depths is developed, an example of carrying out of carotid elastography is shown.

Keywords: ultrasonic vibrations, elastography, atherosclerotic plaques, shear wave

\section{${ }^{1}$ Витвицкая Л.А., ${ }^{2}$ Лаврук Х.3., ${ }^{1}$ Чуйко М.М., ${ }^{2}$ Витвицкий 3.Я.}

${ }^{1}$ Ивано-Франковский национальный технический университет нефти и газа

${ }^{2}$ Ивано-Франковский национальный медицинский университет

\section{РАСШИРЕННЫЙ МЕТОД ЕЛАСТОГРАФИИ КРОВОНОСНЫХ АРТЕРИЙ}

Проведен анализ существующих методов ультразвукового контроля человеческого организма. Обоснована целесообразность проведения эластографии сонных артерий с целью диагностики атеросклероза и степени неподвижности атеросклеротических бляшек в сосудах. Теоретически обоснована целесообразность проведения эластографии на сдвиговых волнах, которые возникают при использовании радиационного давления сильно сфокусированного ультразвукового импульса. Разработана конструкция электронного ультразвукового сканера, который обеспечивает высокую чувствительность принятых сигналов на разных глубинах с высоким разрешением. Определены параметры ультразвуковых датчиков, разработана методика проведения исследования, которая обеспечивает проведение контроля на разных глубинах, показан пример проведения эластографии сонных артерий.

Ключевые слова: ультразвуковые колебания, эластография, атеросклеротические бляшки, сдвиговая волна 